In Press (pre-printed with kind permission) in Encyclopaedia of Water, Wiley Publishers, 2006.

\title{
USING ECOSYSTEM PROCESSES IN A CONSTRUCTED WETLAND TO TREAT MINE WASTEWATER IN IRELAND
}

\author{
Aisling D. O'Sullivan and Marinus L. Otte
}

National University of Ireland at Dublin

\section{Wastewater generation}

The development and expansion of industrial and agricultural activities in the western world has led to a corresponding increase in the release of potentially toxic chemicals into the environment (Catallo, 1993, Schuurmann \& Markert, 1998). Although this growth has had many socio-economic benefits, it has also led to negative implications for wetland ecosystems. For instance, the intensive farming practices developed in Ireland in the 1970s led to eutrophic (over-enriched) rivers and lakes as a result of inadvertent inputs of excess nitrogen and phosphorus. This resulted in algal blooms, subsequent fish mortality and lowered the biodiversity of aquatic systems (Foras Forbartha, 1990). The breaching of tailings dam walls in mine storage ponds has also resulted in catastrophic impacts on neighboring watersheds, which in many circumstances has led to irreversible ecosystem damage (Mora, 2001). Therefore, a balance between reducing undesirable impacts while facilitating positive economic progress is sought. By understanding the complex processes that affect the biogeochemistry and cycling of contaminants in aquatic ecosystems, innovative treatment technologies can be applied to mitigate and treat these wastes (Dunbabin \& Bowmer, 1992, Hedin et al., 1994).

During metal mining, the oxidation of ores frequently results in increased reactivity and bioavailability, and possibly toxicity of heavy metals (Schnoor \& Zehnder, 1996). Since many contaminants such as heavy metals and radionuclides cannot be chemically degraded, microbial deactivation (mainly through immobilization) is most suitable for the treatment of these types of wastes (Salt et al., 1995). Other pollutants that prove difficult to dispose of are Polychlorinated Biphenyls (PCBs) which were used liberally as additives in the manufacture of paints and plastics until their toxicity was realized in the mid 1960s. PCBs have very high chemical, thermal and biological stability and it is these properties which resulted in their bioaccumulation in sediments and biota. Excess plant nutrients such as nitrogen and phosphorus are typically easier to treat in waters since they can be easily assimilated by plants and algae.

\section{Current treatment practices and alternative options}

Conventional practices for the treatment of wastewater in Ireland predominantly adopt chemical applications that require high energy demands. These traditional technologies typically include the chemical manipulation of contaminants and subsequent physical precipitation of suspended solids in the water. Other means of treating wastewater contaminated with biodegradable organic wastes have proven very successful in the past few decades as wastes are biologically converted into gaseous and solid forms. Treatment practices relying on biological processes include continuous activated sludge reactors, which operate either aerobically or anaerobically. In suspended reactor vessels, 
microorganisms are kept in suspension in the wastewater while in attached systems microbial masses adhere typically to an inert medium. Various modifications of the aerobic treatment processes have been developed and include stabilization ponds, aerated waste reservoirs and rotation and filtration techniques (Gray, 1999). These treatment techniques rely principally on activated processes, that is, they require substantial energy inputs and risk failure without continuous energy inputs.

Non-activated biological processes employed for the degradation of contaminants are a more recent practice in wastewater treatment. Worldwide, particularly in North America and Australia, emerging practices for treating wastewater include constructed wetlands. These systems operate using natural processes and usually do not require substantial energy inputs. The biological processes are typically solar-driven as light and carbon sources (from the substrate) are used to drive the microbial and plant processes. Therefore, constructed wetlands can be economical and ecologically acceptable. Typically, constructed wetlands are designed specifically for the type of wastewater being treated. While nutrients can be removed in aerobic systems, sulfate and metals can be removed from wastewater under chemically reducing conditions. Wastewater contaminated by metals has usually been treated primarily for reducing acidity, but some treatment options for this type of waste have shown that substantial metals can be removed concurrently (Hedin et al., 1994).

\section{The Tara Mines case study}

Tara Mines Ireland, a subsidiary of the Finnish company Outokumpu-Zinc, is the largest producer of zinc in Europe and the fifth largest lead-zinc mine worldwide. They are operating since 1977 and supply approximately $20 \%$ of the European demand for zinc (O'Leary, 1996). The local bedrock from where the ore is extracted is classified as Lower Carboniferous calcite $\left(\mathrm{CaCO}_{3}\right)$ and dolomite $\left(\mathrm{CaMgCO}_{3}\right)$, which buffers the wastewater used in the processing operations to a $\mathrm{pH}$ of approximately 7.8 (O'Leary, 1996). Spent water is pumped to large storage ponds for treatment at a site circa $5 \mathrm{~km}$ from the ore extraction site. Some of this wastewater is fed to the experimental treatment wetlands described here.

Treatment wetlands were engineered on site at Tara Mines in 1997. These wetlands were built specifically to treat sulfate and metal enriched wastewater emanating from the mine and represented the only treatment wetlands of this kind in Europe at the time of this publication. Most applications employing microbes to reduce levels of contaminants in wastewater have focused on metal removal (Song et al., 1998), while the research at Tara Mines was concerned primarily with treating sulfate from the alkaline mine water.

\section{Construction design at Tara Mines wetlands}

Two similar experimental treatment systems were built adjacent to large tailings ponds. Each system measured $12 \mathrm{~m}$ (length) X $3 \mathrm{~m}$ (width) X $2 \mathrm{~m}$ (depth) or $72 \mathrm{~m}^{3}$ with a 4:1 (length to width) aspect ratio (after Crites, 1994) and comprised three $12 \mathrm{~m}^{2}$ in-series surface flow cells, viz., inflow, wetland and outflow (see image 1 for details). Both systems were lined with a 2,000 gauge (light insensitive) impermeable PVC material and each wetland cell was planted with cattails (Typha latifolia), reed (Phragmites australis) and floating sweetgrass (Glyceria fluitans) in ratio of 4:9:7 per $\mathrm{m}^{2}$. Three wooden baffles 
coated with an industrial grade waterproof varnish were also placed in each wetland cell and increased the length of the flow path of the water. Mesocosm experiments indicated that an optimal combination of plant growth and substrate permeability was achieved with media containing spent mushroom substrate and fine grit in a ratio by volume of 1:3. Each cell was filled with a similar mix of this substrate to a depth of about $50 \mathrm{~cm}$.

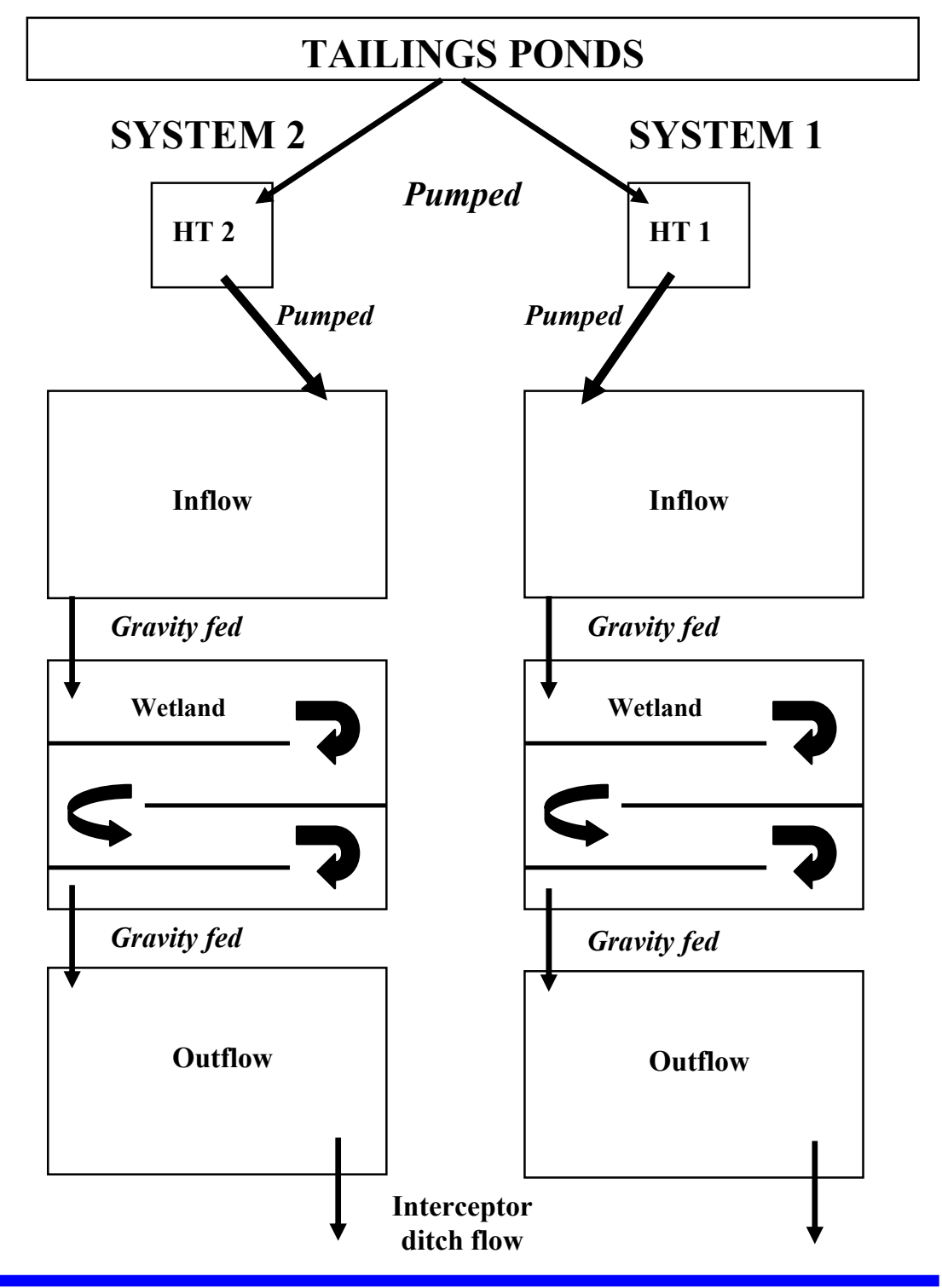

Schematic representation of the experimental treatment wetlands at Tara Mines Ireland. Arrows indicate the flow path of the water, which was pumped from the storage ponds to the header tanks (HT 1 and HT 2) and subsequently to the inflow cells of each system. From there on, water traveling between cells was gravity fed (by head differences between cells) to the wetland cells and then finally to the outflow cells. 


\section{Biogeochemistry - the key to remediation}

Wetland plants can remove pollutants from contaminated soils and water through uptake, translocation and compartmentalization in their tissues (Otte et al., 1995, Salt et al., 1995). However, the more significant influence of plants on metal removal from wastewater is indirectly through accumulation of metals in the sediments neighboring their roots (Otte et al., 1995, Ye et al., 1998). Sufficient organic mater, provided through seasonal plant die-back, is also important in treatment systems that operate on natural biological processes. The accumulation of these contaminants is governed by microbial reactions mediated in suitable substrates and under appropriate conditions. For instance, the substrates used in the treatment wetlands at Tara Mines contained indigenous populations of sulfate-reducing bacteria, identified as the genera Desulfovibrio, Desulfobulbus, Desulfotomaculum and Desulfoccus. The systems were permanently flooded and this provided net anaerobic substrate conditions conducive to the chemical reduction of sulfate $\left(\mathrm{SO}_{4}{ }^{2-}\right)$ to sulfide $\left(\mathrm{S}^{2-}\right)$. This reaction occurred as the microorganisms assimilated sulfate in the absence of oxygen, thus reducing it to sulfide through the transfer of electrons produced by the simultaneous oxidation of the organic substrate. Sulfide anions resultant of the reaction are very unstable and readily react with free or sorbed metal cations forming metal sulfides such as zinc sulfide $(\mathrm{ZnS})$, lead sulfide $(\mathrm{PbS})$ and iron sulfide (FeS) (Morse et al., 1987). Additionally, sulfide can react with hydrogen forming hydrogen sulfide. Once the overlying water became saturated with hydrogen sulfide it was evolved to the atmosphere as a gas. Although evolution of this gas has not yet been quantified, it appears that substantial amounts were produced in the Tara Mines treatment wetlands as evident from the frequent detection (olfactory). In the Tara Mines case study, the capacity to treat metal and sulfate contaminated wastewater using natural ecosystem processes was successfully demonstrated.

\section{Success story - in many ways}

\section{Treatment capacity}

The experimental treatment wetlands were modeled on the surface-flow design, previously established in North America. Effectively, treatment occurred through bioimmobilization of the contaminants in the water as substrate, vegetation and microbial assemblages interacted at the sediment-water interface. Although sulfate concentrations exiting the treatment systems were not compliant with acceptable discharge levels (of 200 $\left.\mathrm{mg} \mathrm{L}^{-1}\right)$ stipulated in national legislation, up to $69 \%$ of the influent concentration $(900 \mathrm{mg}$ $\mathrm{L}^{-1}$ ) was removed and this equated to a removal rate of $29 \mathrm{~g} \mathrm{~m}^{-2}$ day $^{-1}$. Similarly, zinc and lead were removed by up to $99 \%$ and $64 \%$ respectively of the original concentrations supplied of $1.8 \mathrm{mg} \mathrm{Zn} \mathrm{L}^{-1}$ and $0.2 \mathrm{mg} \mathrm{Pb} \mathrm{L}^{-1}$. Concentrations of these metals and of sulfides in the sediments were significantly greater than in the original substrates, while concentrations in the soil water were also elevated compared to background water levels. Plants contained less than $1 \%$ of sulfur in their tissues in accordance with other studies. Vegetation (including algae that voluntarily colonized the systems) sequestered metals to some extent but plant roots had almost double the concentration of metals compared to plant shoots. This may be explained by selective uptake mechanisms exhibited by some plants that can prevent contaminants from traveling to their shoots. The effect may also be explained by metal hydroxides that can form on plant roots (Doyle \& Otte, 1997). 
These hydroxides form when localized oxygenation by wetland plant roots and rhizomes induce precipitation of metals. Once metals are precipitated from solution, they become relatively immobile and thus generally less available to living organisms. Since the vegetation was not harvested from the treatment wetlands, metals in these tissues were not actually removed from the systems as plant uptake and decay results in the cycling of metals within such ecosystems. The most important attributes for ensuring long-term success and sustainability of constructed wetlands treating these kinds of wastes appear to be wetland size and chemical loading rates. Therefore these considerations must be clearly evaluated prior to the construction of treatment wetlands.

\section{Ecological and societal benefits}

Wetlands are recognized for their hydrologic, economic, ecological and aesthetic values. Natural, restored and constructed wetlands have become the focus of many scientists in recent years for their capacity to treat wastewater in an ecologically and economically cost-effective way (Mitsch \& Gosselink, 2000). The ecological benefits provided by the Tara Mines treatment wetlands were diverse and innumerable. Soon after they were constructed, macroinvertebrates (35 taxa), plants (6 species), algae and microorganisms voluntarily colonized the systems. The vegetation afforded refuge to birds (e.g. Moorhen) and other wildlife (foxes, rabbits, shrews etc.), while also providing niches for microbial and invertebrate communities.

It is obvious that surface flow wetlands offer many ancillary benefits by creating new habitats for wildlife. Initiatives to develop treatment wetlands have frequently involved local communities and educational establishments, thereby integrating educational principals into their goals. Aspects of the study at Tara Mines have been delivered to a wide spectrum of society from high-school teenagers in the local community to undergraduate and postgraduate students in Universities in Ireland, Europe and the USA. Additionally, the work has been well received by industries and local interests groups. By involving communities in the construction of wetlands, awareness is generated of the value of such ecosystems and their capacity to recycle wastes by biological and ecologically acceptable techniques.

\section{Treatment success compared with other systems}

Performance of the Tara Mines treatment wetlands, for sulfate and metal removal, was compared with that of other studies. Many of the other investigations quantified removal as a percentage of the influent concentration, but mass removal rates represent a more realistic estimate of the actual amount removed (Hedin et al., 1994). In this instance, contaminant removal is calculated from a loading perspective and considers flow rates, concentrations, wetland size and expresses removal per unit time. Sulfate removal at Tara Mines was comparable with that published by Eger (1994) of up to $27 \mathrm{~g}$ $\mathrm{m}^{-2}$ day $^{-1}$. Metal removal (from a percentage perspective) at Tara Mines was usually greater than that of other studies (e.g. Mays \& Edwards, 2001; removal of 33\% Zn and $26 \% \mathrm{~Pb}$ ). However, metal levels in the wastewater treated in the other studies were greater than that in the Tara Mines wastewater and so larger mass removal rates probably occurred in these other studies. 


\section{Stimulus for revising waste management practices}

In the past 25 years, most treatment wetland studies were concerned with the removal of plant nutrients from water. In the last decade, this focus has shifted towards remediating mine wastewater, principally for reducing the impact of acid mine drainage (Hedin et al., 1994). However, constructed wetlands built for treating mine waste were primarily developed in North America, while the scope of similar systems in Europe has yet to be demonstrated. However, the question of long-term reliability of treatment wetlands is still not conclusively answered since most systems of this type are operating for less than 15 years (Hedin, 1996), although many scientists will advocate that once they are appropriately designed and managed, they can remain self-renewing for several decades. The development of constructed wetland technology has demonstrated attractive success rates and limited financial operational costs are incurred. They can also provide ancillary ecological benefits. Increasing pressure in preparing for mine closure following ore exhaustion, coupled with societal concerns regarding environmental quality, is pressurizing industries to re-evaluate conventional treatment practices. Recent Irish and European Union legislation has contributed in some ways towards increasing the awareness of alternative cost-efficient treatment practices allying with sustainable development. By exploiting this new-found awareness, the scope for implementing some innovative, ecologically sound waste technologies looks promising.

\section{Acknowledgements}

The authors wish to acknowledge the financial support of Tara Mines Ireland and Enterprise Ireland for the research project. Dr Declan Murray is also acknowledged for his involvement in the research project and our colleagues in the School of Biological and Environmental Sciences (UCD, Ireland) for their assistance in the field while constructing the treatment wetlands.

\section{Literature cited}

Catallo, W. "Ecotoxicology and wetland ecosystems - current understanding and future needs". Environmental Toxicology and Chemistry 12(12), 2209-2224 (1993).

Crites, R. "Design criteria and practice constructed wetlands". Water, Science and Technology 29(4), 1-6 (1994).

Doyle, M \& Otte, M. "Organism-induced accumulation of iron, zinc, and arsenic in wetland soils". Environmental Pollution 96, 1-11 (1997).

Dunbabin, J. \& Bowmer, K. "Potential use of constructed wetlands for treatment of industrial wastewaters containing metals". The Science of the Total Environment 111, 151-168 (1992).

Eger, P. " Wetland treatment for trace metal removal from mine drainage: the importance of aerobic and anaerobic processes". Water, Science and Technology 29(4), 249-256 (1994).

Foras Forbatha. "Water resources division in eutrophication (1986-1990)". Publication of the (Irish) National institute for planning and construction research (1990).

Gray, N. Water technology - an introduction for environmental scientists and engineers. John Wiley \& Sons, Inc., New York, 1999, pp. 302-320.

Hedin, R. "Environmental engineering forum: long-term effects of wetland treatment of mine drainage". Journal of Environmental Engineering 122, 83-85 (1996). 
Hedin, R., Nairn, R. \& Kleinmann, R. "Passive treatment of coal mine drainage". Information Circular \# 9389, Bureau of Mines, US Department of the Interior (1994).

Mays, P. \& Edwards, G. "Comparison of heavy metal accumulation in a natural wetland and constructed wetlands receiving acid mine drainage". Ecological Engineering 16: 487500 (2001).

Mitsch, W. \& Gosselink, J. Wetlands. (3rd Edition), Van Nostrand Reinhold, New York, 2000, pp. 688-697.

Mora, A. "Solutions applied to Aznalcollar disaster". Abstracts of the COST Action 837 (WG2) Workshop; Phytoremediation of trace elements in contaminated soils and water, (Ed.) C. Camara pp. 29, University of Madrid, Spain, April 5-7 $7^{\text {th }}$ (2001).

Morse, J., Millero, F., Cornwell, J. \& Richard, D. "The chemistry of the hydrogen sulfide and iron sulfide systems in natural waters". Earth Science Reviews 24, 1-42 (1987).

O'Leary, W. "Wastewater recycling and environmental constraints at a base metal mine and process facilities". Water, Science and Technology 33(10-11), 371-379 (1996).

Otte, M., Kearns, C. \& Doyle, M. "Accumulation of arsenic and zinc in the rhizosphere of wetland plants". Bulletin Environmental Contamination and Toxicology 55, 154-161 (1995).

Salt, D., Blaylock, M., Kumar, N., Dushenkov, V., Ensley, B., Chet, I. \& Raksin, I. "Phytoremediation: a novel strategy for the removal of toxic metals from the environment using plants". Biotechnology 13, 468-473 (1995).

Schuurmann, G. \& Markert, B. Ecotoxicology. John Wiley \& Sons, London, 1998.

Schnoor, J. \& Zehnder, A. Environmental modeling: fate and transport of pollutants in water, air and soil, John Wiley \& Sons, Inc., New York, 1996, pp. 381-451.

Song, Y., Piak, B., Shin, H. \& La, S. "Influence of electron donor and toxic materials on the activity of sulfate reducing bacteria for the treatment of electroplating wastewater". Water, Science and Technology 38(4-5), 187-194 (1998).

Ye, Z., Baker, A., Wong, M. \& Willis, A. "Zinc, lead and cadmium accumulation and tolerance in Typha latifolia as affected by iron plaque on the root surface". Aquatic Botany 61, 55-67 (1998). 